\title{
Food and feeding habits of Gagata youssoufi (Rahman) from the river Padma in Rajshahi
}

\author{
Md. Abdur Razzaq Joadder \\ Department of Fisheries, University of Rajshahi, Rajshahi 6205, Bangladesh
}

Gagata youssoufi (Rahman) is a riverine catfish, commonly known as Gang tengra or Kyakata. In Bangladesh it is available in the northern and southern parts and mainly found in Padma, Meghna, Brahmaputra and Jamuna rivers. This fish is also found in many countries like Pakistan, India, Nepal and Burma (Talwar \& Jhingran, 1991). Its body length varies from 3.5 to $11 \mathrm{~cm}$. G. youssoufi is considered to be one is the most important fishes for its taste and highly nutritive value. This small fish is a good source of protein, calcium, essential amino acids, phosphate and vitamin A. Feeding is the dominant activity of the entire life cycle of fish (Royce, 1972). The success on good scientific planning and management of fish species largely depends on the knowledge of their biological aspects, in which food and feeding habits include a valuable portion. Nutrition of fish is directly related with the amount of fish production. Studies on the seasonal patterns of feeding habits of fishes have been made by many workers at home and abroad (Das \& Moitra, 1955; Nargis \& Hossain, 1987; Hynes, 1990). A comparative study on the food and feeding habits of Puntius stigma, Mystus vittatus and Nandus nandus has been reported by Ahmed et al. (1993). Moreover, seasonal patterns of feeding of the freshwater fish, Colisa fasciata (Bloch) by Mustafa et al. (1981) and food of the fry of Cirrhina mrigala (Hamilton) by Bhuiyan \& Islam (1991) are noteworthy. But no published information is available on the food and feeding habits of $G$. youssoufi. This led to the present study that would help to select this species for culture, and to produce an optimum yield by utilizing all the potential food of the water bodies.

A total number of 339 specimens of $G$. youssoufi were collected during November 2004 and October 2005 from the river Padma in Rajshahi Metropolis in every month with the help of cast nets, dip nets and drag nets (Tana jal). Immediately after collection, 70\% alcohol was injected into the guts of all the fishes in order to stop digestion of food items. The stomach contents of all the specimens were noted and the stomachs were classified into full, 3/4 full, 1/2 full, 1/4 full, 1/8 full and empty. The stomach of each specimen was dissected with a pair of fine scissors and stomach contents were taken. Alimentary canal length (ACL) was measured and weight of food of each fish was recorded using an electronic balance (Model-400EX, MFD by A \& D Co. Ltd., Korea). The percentages of different food items were calculated month-wise by using gravimetric method. Afterwards the undigested gut contents were estimated under simple and binocular microscopes at each $10 \times$ and categorized them under different taxonomic hierarchy by following Ward \& Whipple (1959), Mellanby (1963) and Needham \& Needham (1972). Relationship between the total length (TL) and ACL was established by using the statistical formula: $\mathrm{Y}=\mathrm{a}+\mathrm{bX}$.

The monthly percentages of stomach condition of $G$ youssoufi are shown in Table 1 . Out of 339 stomachs, 290 (85.83\%) were with food and 49 (14.57\%) were empty. Of 290 stomachs, 76 were full, 65 were $3 / 4$ full, 66 were 1/2 full, 40 were $1 / 4$ full, 43 were $1 / 8$ full. The highest percentage of fullness of the stomachs was observed in January and September (41.93\%). After these months the percentage of fullness gradually decreased and it was least in March (3.03\%). The highest percentage of empty stomachs was found in March (45.45\%), after which the percentage of emptiness gradually decreased and the lowest percentage of emptiness was found in April (2.86\%). The mean TL of the fishes was $7.37 \pm 2.57 \mathrm{~cm}$ and the mean ACL was $7.15 \pm 3.24 \mathrm{~cm}$. The TL and ACL ratio was 1: 0.97 , the calculated regression equation was $\mathrm{ACL}=-2.0866+1.2525 \mathrm{TL}(\mathrm{r}=0.98)$.

The results on the stomach contents of G. youssoufi are presented in Table 2. The stomach contents consisted mainly of crustaceans (14.12\%), insects and their larvae (13.12\%), mosquitoes and their larvae (12.88\%), and parts of aquatic plants (12.18\%). The less significant food groups were mollsucs (11.05\%), algal filaments (11.74\%), fish scales (9.89\%), sand and mud (9.12\%) and unidentified food materials (5.86\%). The occurrence of various food groups varied from during the year. The crustacean food items consisted mainly of Cyclops, Daphnia, Cypris and Diaptomus whereas larvae of identified insects and mosquitoes and their larvae, larvae and adults (parts) of Anopheles and Culex, and plant parts composed of dry stems and 1

eaves. The highest percentage of crustaceans was recorded in the month of January (23.05\%) and the lowest in May (6.21\%). The highest percentage of insects and their larvae was observed in the month of October (17.50\%) and the lowest in April (8.55\%). The 
highest percentage of mosquitoes and their larvae was recorded in June (23.77\%) and the lowest in November (5.58\%). The highest percentage of aquatic plant parts was recorded in May (19.15\%) and the lowest in January (1.5\%). Algal filaments of Spirogyra, Trichita,
Chlorolla, Losmarium, Crucigenia, Dedogonium, Chara and Ckroococuis were observed. The highest percentage of this food item was observed in November (17.82\%) and lowest (3.15\%) in April.

Table 1. The monthly percentage of the stomach condition of G. youssoufi

\begin{tabular}{|c|c|c|c|c|c|c|c|c|}
\hline \multirow[t]{2}{*}{ Years } & \multirow[t]{2}{*}{ Months } & \multirow{2}{*}{$\begin{array}{l}\text { No. of fish } \\
\text { examined }\end{array}$} & \multicolumn{6}{|c|}{ Stomach condition } \\
\hline & & & Full & $3 / 4$ full & $1 / 2$ full & $1 / 4$ full & $1 / 8$ full & Empty \\
\hline \multirow{2}{*}{2004} & Nov & 25 & 24 & 20 & 16 & 20 & 12 & 8 \\
\hline & Dec & 27 & 25.92 & 18.52 & 7.41 & 18.52 & 11.11 & 18.52 \\
\hline \multirow{10}{*}{2005} & Jan & 31 & 41.93* & 22.58 & 16.13 & 9.68 & 6.45 & 6.45 \\
\hline & Feb & 29 & 24.14 & 34.48 & 13.79 & 17.24 & 6.89 & 3.45 \\
\hline & Mar & 33 & 9.09 & 21.21 & 15.15 & $3.03^{*}$ & 6.07 & $45.45^{*}$ \\
\hline & Apr & 35 & 14.28 & 34.14 & 25.71 & 5.71 & 14.28 & $2.86 *$ \\
\hline & May & 22 & 13.64 & 27.27 & 9.09 & 22.73 & 18.18 & 9.09 \\
\hline & Jun & 23 & 8.69 & 13.04 & 21.74 & 8.69 & 21.74 & 26.08 \\
\hline & Jul & 29 & 10.34 & 10.34 & 31.03 & 17.24 & 13.79 & 17.24 \\
\hline & Aug & 21 & 33.33 & 9.52 & 14.28 & 9.52 & 14.28 & 19.04 \\
\hline & Sep & 31 & 41.93* & 9.68 & 29.03 & 6.45 & 3.22 & 9.68 \\
\hline & Oct & 33 & 24.24 & 6.06 & 33.33 & 12.12 & 15.15 & 9.09 \\
\hline \multicolumn{3}{|c|}{ \% occurrence average of 12 months } & 22.62 & 19.15 & 19.39 & 11.93 & 12.74 & 14.57 \\
\hline
\end{tabular}

Table 2. The monthly percentage composition of the food items of G. youssoufi

\begin{tabular}{|c|c|c|c|c|c|c|c|c|c|c|c|}
\hline Years & Months & $\begin{array}{c}\text { No. of } \\
\text { fishes } \\
\text { examined }\end{array}$ & Molluscs & Crustacean & $\begin{array}{c}\text { Insect and } \\
\text { their } \\
\text { larvae }\end{array}$ & $\begin{array}{c}\text { Mosquito } \\
\text { and their } \\
\text { larvae }\end{array}$ & $\begin{array}{c}\text { Algal } \\
\text { filament }\end{array}$ & $\begin{array}{l}\text { Fish } \\
\text { scales }\end{array}$ & $\begin{array}{c}\text { Parts of } \\
\text { aquatic } \\
\text { plants }\end{array}$ & $\begin{array}{c}\text { Sand } \\
\text { and } \\
\text { mud }\end{array}$ & $\begin{array}{c}\text { Unidentified } \\
\text { food } \\
\text { materials }\end{array}$ \\
\hline \multirow{2}{*}{2004} & Nov & 25 & 14.5 & 18.5 & 15.50 & 5.58 & 17.82 & 10.15 & 7.5 & 3 & 7.45 \\
\hline & Dec & 27 & 9.15 & 21.75 & 13.10 & 9.75 & 16.45 & 7.17 & 12.05 & 7.75 & 2.83 \\
\hline \multirow{10}{*}{2005} & Jan & 31 & 12.25 & 23.05 & 13.15 & 8.85 & 11.75 & 0 & 1.5 & 25.75 & 3.6 \\
\hline & Feb & 29 & 9.98 & 17.5 & 12.45 & 11.05 & 8.5 & 0 & 10.75 & 23.5 & 6.27 \\
\hline & Mar & 33 & 11.25 & 15.76 & 9.25 & 13.26 & 7.89 & 0 & 12.65 & 19.98 & 9.96 \\
\hline & Apr & 35 & 4.75 & 7.72 & 8.55 & 21.73 & 3.15 & 18.23 & 15.52 & 14.21 & 6.14 \\
\hline & May & 22 & 3.25 & 6.21 & 9.65 & 12.37 & 9.81 & 16.35 & 19.15 & 13.75 & 9.26 \\
\hline & Jun & 23 & 3.15 & 10.97 & 13.15 & 23.77 & 12.89 & 9.32 & 16.37 & 1.5 & 8.88 \\
\hline & $\mathrm{Jul}$ & 29 & 4.45 & 8.35 & 15.57 & 19.75 & 14.9 & 13.79 & 15.82 & 0 & 7.07 \\
\hline & Aug & 21 & 19.5 & 13.79 & 17.30 & 11.29 & 9.5 & 9.98 & 14.01 & 0 & 4.63 \\
\hline & Sep & 31 & 21.75 & 13.05 & 12.25 & 7.95 & 14.28 & 15.55 & 13.71 & 0 & 1.46 \\
\hline & Oct & 33 & 18.65 & 12.75 & 17.50 & 9.15 & 13.87 & 18.15 & 7.15 & 0 & 2.78 \\
\hline \multicolumn{3}{|c|}{$\begin{array}{c}\text { \% occurrence average of } 12 \\
\text { months }\end{array}$} & 11.05 & 14.12 & 13.12 & 12.88 & 11.74 & 9.89 & 12.18 & 9.12 & 5.86 \\
\hline
\end{tabular}

Molluscs consisted of Pila, bivalves and other snails. The highest percentage of molluscs was observed in September (21.75\%) and lowest in June (3.15\%). Fish scales, small fishes, fish fries and fish eggs were recorded the highest in April (18.23\%) and the lowest in December (7.17\%). There was no fish scale from the months of January to March. The highest percentage of sand and mud was recorded in January (25.75\%) and lowest in the month of June (1.5\%). Sand and mud were absent from July to October. The highest percentage of unidentified food materials was found in March $(9.96 \%)$ and the lowest in September (1.46\%). The maximum number of empty stomachs was recorded in March (45.45\%) and the higher percentage of full stomachs were observed from August to January. The adult fish was found to be poorly feed during February and July. This period of poor feeding activity coincided with the peak spawning season because the abdominal cavity is fully occupied by the voluminous ripe gonads and so the stomachs were always empty and small in size. Thomas (1969) stated that this low feeding activity may not be due to shortage of food items but due to the spawning season of the fish. Dewan \& Saha (1979) reported that the low feeding activity of Tilapia in the months of February to June is associated with fecundity of the water produced by heavy rain fall, whereas the immature fishes were found to actively feeding in all other months. Keast (1965) reported that many fishes change their food habits as they grow. These findings clearly indicate that the feeding intensity in juvenile fishes is increased remarkably.

The crustaceans and molluscs were very dominant food items in G. youssoufi throughout the year. It is 
observed that G. youssoufi feeds in all the months of a year and the change of season. Ompok pabda (Bhuiyan \& Islam, 1991), Aspidoparia morar and Clupisoma atherinoides shared similar food preference (Bhuiyan et al., 1992; 1997). Mustafa et al. (1982) recorded more or less the same food items along with rotifers in Puntius sarana. From the analysis of food in the gut contents, it is evident that $G$. youssoufi is neither a true surface feeder nor a true bottom feeder, rather its food substances mainly consisted of crustaceans, molluscs, plant parts, fish scales, algal filaments and sand and mud were distributed throughout the different layers of the water bodies. On the basis of different food items found in the stomach contents, G. youssoufi may therefore be conveniently regarded as an omnivorous catfish.

\section{References}

Ahmed, A.T.A., Rahman, M.M., Mustafa, G. \& Sanaullah, M. 1993. A comparative study of food and feeding habits of three species of fish from Beel Mahmeud, Faridpur. Bangladesh J. Zool . 21(1): 11-21.

Bhuiyan, A.S. \& Islam, M.N. 1991. Observation on the food and feeding habit of Ompok pabda(Ham.) from the river Padma. Pakistan J. Zool. 23(1): 75-77.

Bhuiyan, A.S., Begum, M. \& Nessa, Q. 1997. Observation on the food feeding habit of Clupisoma atherinoides (Bloch). Univ. j. zool. Rajshahi Univ. 16: 1-5

Bhuiyan, A.S., Islam, M.N. \& Sultana, N. 1992. Food and feeding habit of Aspedoparia morar (Ham.) from the river Padma. Univ. j. zool. Rajshahi Univ. 10\&11: 71-76.

Das, M. \& Moitra, X. 1955. Studies on the food of some common fishes of Uttar Pradewsh, India. Proc. National Acad. Sci. India. parts I-II, Section. O, Vol. 25.
Dewan, S. \& Saha, S.H. 1979. Food and feeding habit of Tilapia nilotica (L): Diet and seasonal pattern of feeding. Bangladesh J. Zool. 7: 75-80.

Hynes, H.B.N. 1990. The food of freshwater stickleback with a review of the methods used in studies of fishes. $J$. Anim. Ecol. 19: 41-57.

Keast, A. 1965. Feeding biology of the Black Crappie. Pomoxis migromaculatus. J. Fish. Res. 25: 285-297.

Mellanby, H. 1963. Animal Life in Freshwater (6 $6^{\text {th }}$ edn.). Methuen \& Co.Ltd. London. 300 pp.

Mustafa, G., Islam, K.R. \& Ali, S. 1981. Seasonal patterns of feeding of the freshwater fish Colisa fasciata (Bloch) Bangladesh J. Zool. 9( I): 49-50.

Mustafa, M., Islam, K.R., Ali, S. \& Alam, A.K.M.A. 1982. Some aspect of the biology of Puntias sarana (Ham.): Food and feeding habit in relation to fish size and fecundity. Bangladesh J. Zool. 10(2): 92-100.

Nargis, A. \& Hossain, M.A.1987. Food and feeding habit of Koi fish, Anabas testudineus. Bangladesh J. Agric. 12: 121-127.

Needham, J.G. \& Needham, R.P. 1972. A Guide to the Study of Freshwater Biology. Holden-Day, Inc. California, USA.

Rahman, A.K.A. 1989. Freshwater Fishes of Bangladesh $\left(1^{\text {st }}\right.$ edn). The Zoological Society of Bangladesh. 364 pp.

Royee, W.F. 1972. Introduction to the Fishery Science. Academic Press. New York.

Talwar, P.K. \& Jhinagran, A.G. 1991. Inland Fishes of India and Adjacent Countries. Vols. I \& II. Oxford \& IBH Publishing Co. Pvt. Ltd. New Delhi, India.

Thomas, P.A. 1969. Goat fishes (Fam. Mullidae) of the Indian seas. Mar. Biol. Assoc. India Memoir.III.7: 152-157.

Ward, H.B. \& Whipple, G.C. 1959. Freshwater Biology. John Willey \& Sons. Inc. New York.

Revised manuscript received on 27 June 2007. 
